\title{
The Effect of Health Education with Flashcard Media on Improvement of Knowledge and Reduction of Anxiety Degree in Adolescents Primigravida
}

\author{
Dwie Yunita Baska, ${ }^{1,2}$ Tita Husnitawati Madjid, ${ }^{3}$ Ponpon S. Idjradinata ${ }^{4}$ \\ ${ }^{1}$ Department of Midwifery, Politeknik Kesehatan Kementerian Kesehatan Bengkulu, Bengkulu, Indonesia, \\ ${ }^{2}$ Midwifery Master Study Program, Faculty of Medicine, Universitas Padjadjaran, Bandung, Indonesia, \\ ${ }^{3}$ Department of Obstetrics and Gynecology, Faculty of Medicine, Universitas Padjadjaran/Dr. Hasan \\ Sadikin General Hospital, Bandung, Indonesia, ${ }^{4}$ Department of Child Health, Faculty of Medicine, \\ Universitas Padjadjaran/Dr. Hasan Sadikin General Hospital, Bandung, Indonesia
}

\begin{abstract}
The education about the reproductive health of pregnancy is needed to increase knowledge and reduce anxiety in adolescent primigravida, one of them is by conducting flashcard media. Flashcards are pictorial media in the form of cards that have words; it's proven to be able to create fun learning, attracts attention, and stimulates critical thinking. The purpose of the study was to analyze the effect of education with flashcard media on knowledge and anxiety degree in adolescent primigravidas. The research method used in this study was a one-group pretestposttest quasi-experimental design. The number of samples as many as 30 people ( $<20$ years old) at Sawah Lebar Public Health Center and Padang Serai Public Health Center in Bengkulu city from May to July 2018, by using consecutive sampling. The data of this study obtained from pretest and posttest questionnaires of knowledge, and Zung Self-rating Anxiety Scale (ZSAS), Shapiro-Wilk, Wilcoxon, and chi-square test statistics. The results showed a significant increase in knowledge before and after the intervention of $\mathrm{p}$ value $=0.001(\mathrm{p}<0.05)$, an increase in the average score of knowledge of series one card amounts to $35.0 \%$ and knowledge of series $2-3$ card amounted to $30 \%$. A significant decrease in anxiety degree of $9.2 \%$ after the treatment $(\mathrm{p}<0.05)$. In conclusion, flashcards can increase knowledge and reduce the anxiety of adolescents primigravida mothers so that health workers use this educational approach appropriately.
\end{abstract}

Key words: Adolescent primigravida, anxiety, education, flashcard, knowledge

\section{Pengaruh Edukasi Kesehatan dengan Media Flashcard terhadap Peningkatan Pengetahuan dan Penurunan Derajat Kecemasan pada Primigravida Remaja}

\begin{abstract}
Abstrak
Edukasi tentang kesehatan reproduksi kehamilan penting untuk meningkatkan pengetahuan dan mengurangi kecemasan pada primigravida remaja, salah satunya dengan media flashcard. Flashcard adalah media bergambar dalam bentuk kartu yang dilengkapi kata-kata; terbukti mampu menciptakan pembelajaran yang menyenangkan, menarik perhatian, dan merangsang untuk berpikir kritis. Penelitian ini bertujuan menganalisis pengaruh edukasi dengan media flashcard terhadap pengetahuan dan derajat kecemasan pada primigravida remaja. Metode yang digunakan dalam penelitian ini adalah one-group pretest-posttest quasi-experimental design. Jumlah sampel 30 orang (<20 tahun) di Puskesmas Sawah Lebar dan Puskesmas Padang Serai di Kota Bengkulu dari bulan Mei hingga Juli 2018 dengan menggunakan consecutive sampling. Data penilaian didapat dari kuesioner pretest dan posttest pengetahuan, Zung Self-rating Anxiety Scale (ZSAS), Shapiro-Wilk, Wilcoxon, dan statistik uji chi-square. Hasil penelitian menunjukkan peningkatan yang signifikan pada pengetahuan sebelum dan sesudah intervensi nilai $\mathrm{p}=0,001(\mathrm{p}<0.05)$, kenaikan skor rerata pengetahuan kartu seri $1(35,0 \%)$ serta pengetahuan kartu seri $2-3$ (30\%). Penurunan signifikan derajat kecemasan 9,2\% setelah perlakuan $(\mathrm{p}<0,05)$. Simpulan, flashcard mampu meningkatkan pengetahuan dan menurunkan kecemasan ibu primigravida remaja sehingga pendekatan edukasi ini dianggap efektif bagi pemberi asuhan.
\end{abstract}

Kata kunci: Edukasi, flashcard, kecemasan, pengetahuan, primigravida remaja

Received: 1 October 2019; Revised: 20 April 2020; Accepted: 21 April 2020; Published: 30 April 2020

Correspondence: Dwie Yunita Baska, S.S.T., M.Keb. Department of Midwifery, Politeknik Kesehatan Kementerian Kesehatan Bengkulu. Jln. Indragiri Padang Harapan No.3, Bengkulu 38115, Bengkulu, Indonesia. E-mail: baskadwi@gmail.com 


\section{Introduction}

Indonesia is the $7^{\text {th }}$ country with a high prevalence of young marriage in the world. ${ }^{1}$ The regional average rate of births per 1,000 females $15^{-19}$ years of age is 48 , with the estimated median age at first marriage is 20.4 years for women. ${ }^{2}$

There are many health consequences of early marriage, partly because young mothers are immature and lack access to social and reproductive services. Examples of such problems are increased risks for sexually transmitted diseases, cervical cancer, and transmission of HIV infection, bleeding, miscarriage, death during childbirth, and anemia during pregnancy, as well as increased risks of preeclampsia and eclampsia, obstetric fistula, and obstructed labor. Girls' offspring are at increased risk for premature birth, low birth weight, asphyxia, congenital neonatal infections, and death as neonates, infants, or children. ${ }^{3-5}$

The role of psychological factors in the healthy behaviors of pregnant women is a significant issue. ${ }^{6}$ During pregnancy, women experience hormonal changes, which include estrogen and progesterone, which will cause various complaints such as nausea, vomiting, cravings, and emotional instability; the most prominent is anxiety. ${ }^{-9}$ Lack of knowledge and planning for the pregnancy of mothers about reproductive health problems and changes that occur during pregnancy will undoubtedly increase the anxiety that can increase the risk of pregnancy failure. ${ }^{8}$

When sensory systems detect information or stimulus in the brain, it will create a learning process in a person. The results of processing are stored in memory in the form of knowledge,$^{10}$ and improvement in the learning process can even reduce anxiety by up to $72 \%$ in middle and high school students tested in the final semester. ${ }^{11}$

The provision of care related to psychological aspects is still very minimal in Indonesian society, especially in conducting antenatal care examinations. The importance of health education in adolescent primigravida will increase their knowledge in dealing with pregnancy and make themselves ready to adapt well. Anxiety during pregnancy can be managed and controlled..$^{12,13}$

Effective education needs the media to facilitate the delivery of information and attract the attention of the audience, one of which is the image media or visual media. Flashcard is visual media in the form of picture cards that are equipped with words and measuring $10 \times 12.5 \mathrm{~cm}$ or $25 \times 30 \mathrm{~cm}$. In individual learning, this chosen media can involve more senses following the theory of learning, that humans use $75 \%$ visual and $13 \%$ audio. ${ }^{11,12}$

Flashcard is an effective way used in the teaching and learning process, because it creates fun learning, provides meaningful experience, develops critical thinking skills in life as well as social skills. Flashcard is useful to facilitate repetition because it can translate abstract ideas into a more realistic form. Flashcard makes it easier for educators to provide small pieces of information memorably and interestingly with affordable materials and are easily available in textbooks and magazines. Moreover, it can also save time and energy; attract attention; clarify a problem in various fields, and are used by all ages. Flashcard media can also create fun learning, provide a meaningful experience, develop critical thinking skills in life and social skills. ${ }^{16-19}$

The purpose of the study was to analyze the effect of education with flashcard media on knowledge and anxiety degree in adolescent primigravidas.

\section{Methods}

The research method used in this study was a one-group pretest-posttest quasi-experimental design, conducted in one group of adolescent primigravida, without a control group. The study was in the working area of Sawah Lebar Public Health Center and Padang Serai Public Health Center in Bengkulu city from May to July 2018. The samples in this study were taken by using consecutive sampling or based on the order of arrival of patients who meet the inclusion criteria..$^{20}$ The number of samples was 30 teenage mothers $(<20$ years old), pregnant in the second and third trimesters, and experienced mild to moderate anxiety.

The researchers directly involved not only as of the providers of health education but also for collecting data directly. The activities were carried out in several places, for example, in the public health center, midwife's house, and cadre's house. During activities, the respondents divided into small groups consisting of 6-8 people per group.

The stages of this study activities comprise of three phases. In phase one, knowledge pretest of series one card (maternal pregnancy and infants growth and development) and anxiety questionnaires administered to the respondents, 
then the respondents were given the face-to-face education by using the flashcard media with the lecture and discussion method for \pm 120 minutes.

In phase two (one week later), knowledge pretest of series 2-3 cards (series 2: stages of growth and development of infants, series 3: physiological changes, breast care, and breastfeeding techniques of the puerperal mother) administered to the respondents. Afterward, continued by another session for \pm 120 minutes, while the posttest conducted at the end of the meeting. The level of knowledge converted into a value of 100. It is categorized into a level of knowledge of good if reached $76-100 \%$, adequate if the score is $56-75 \%$, and inadequate if the value is $<56 \%$.

In phase three (one week later), the researchers went to the respondent's house to administer an anxiety posttest. Data analysis of this study used the Shapiro-Wilk test for data normality test, significance test to compare knowledge and anxiety pretest-posttest. The characteristics of the study group analyzed using the Wilcoxon test and chi-square test (x2) with significance criteria of $\mathrm{p}<0.05$, which means the result is significant. ${ }^{21}$

The instruments used in this study were knowledge questionnaires of series one card, series 2-3 cards, and Zung Self-rating Anxiety Scale (ZSAS). The researchers developed information in the flashcard media by referring to several references, with the flashcard design was done by an expert from Visual Communication Design of Institut Teknologi Bandung. Before used, the contents of the flashcard discussed and tested by several experts in educational psychology and a media design expert for the visual approach.

The protocol of this study has approved by the Health Research Ethics Committee, Faculty

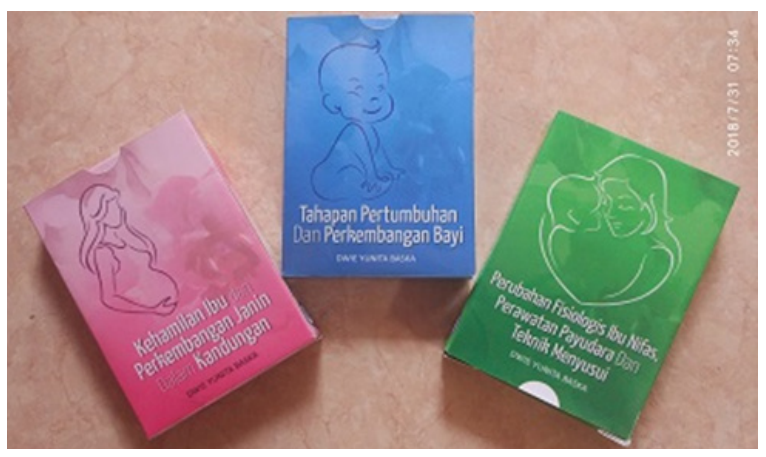

Figure Flashcard Media of Medicine, Universitas Padjadjaran Bandung, with letter number: 548/UN6.KEP/EC/2018.

\section{Results}

Table 1 shows the average age of mothers is 19 years old, mostly in the second trimester of pregnancy, with the education level of high school, dominantly homemakers/unemployed, and the economic status of less than Bengkulu regional minimum wage (upah minimum regional/UMR).

Table 2 shows the comparison of the knowledge scores and the knowledge levels of one card series and a $2-3$ card series. Knowledge scores are significant differences between groups before and after reproductive health education was given with flashcard media. An average increase observed to $35.3 \%$ in the knowledge score of one card series and $30.2 \%$ in the knowledge score of 2-3 card series. Knowledge levels were a significant difference in the before and after results. The group with the reproductive health education treatment with flashcard media, increase from inadequate and adequate knowledge to a good level in all 30 participants.

There was a significant difference in the groups before and after reproductive health education with flashcard media to the degree of anxiety (Table 3). Before being educated, mothers who experienced mild anxiety were 24 people, and who experienced medium anxiety

\section{Table 1 Characteristics of Research Subjects}

\begin{tabular}{lc}
\hline Variables & $\mathbf{n}=\mathbf{3 0}$ \\
\hline Age (years) & \\
Mean \pm Std & $19.40 \pm 0.968$ \\
Median & 20.00 \\
Range (min-max) & $16.00-20.00$ \\
Age of pregnancy & \\
$\quad$ Trimester II & 19 \\
$\quad$ Trimester III & 11 \\
Last education & \\
Elementary school & 1 \\
Middle school & 2 \\
High school & 27 \\
Job status & \\
Employed & 25 \\
$\quad$ Unemployed & 5 \\
Economic status & \\
Less than UMR & 17 \\
More than UMR & 13 \\
\hline
\end{tabular}


Table 2 Differences in Knowledge Score and Knowledge Level of Series 1 Card and Series 2-3 Cards on Interventions before and after the Provision of Reproductive Health Education with Flashcard Media

\begin{tabular}{|c|c|c|c|}
\hline \multirow{2}{*}{ Variables } & \multicolumn{2}{|c|}{ Groups $(n=30)$} & \multirow{2}{*}{ p Value } \\
\hline & Pretest & Posttest & \\
\hline \multicolumn{4}{|l|}{ Knowledge score } \\
\hline \multicolumn{4}{|c|}{ Knowledge of series 1 card } \\
\hline Mean (SD) & 55.0 & 90.3 & $<0.000^{*}$ \\
\hline Median & 56 & 89 & \\
\hline Range (min-max) & $44-72$ & $83-100$ & \\
\hline \multicolumn{4}{|c|}{ Knowledge of series $2-3$ cards } \\
\hline Mean (SD) & 60.0 & 90.2 & $<0.000^{*}$ \\
\hline Median & 61 & 89 & \\
\hline Range (min-max) & $44-72$ & $83-94$ & \\
\hline \multicolumn{4}{|l|}{ Knowledge level } \\
\hline \multicolumn{4}{|l|}{ Card series 1} \\
\hline Inadequate & 13 & o & $0.000^{* *}$ \\
\hline Adequate & 17 & 0 & \\
\hline Good & 0 & 30 & \\
\hline \multicolumn{4}{|l|}{ Card series $2-3$} \\
\hline Inadequate & 5 & 0 & $0.000^{* * *}$ \\
\hline Adequate & 25 & 0 & \\
\hline Good & 0 & 30 & \\
\hline
\end{tabular}

Note: "Wilcoxon test, "* Shapiro-Wilk test

was 6 people. After being educated, mothers who were no anxiety were 20 people, who experienced mild anxiety were 10 people, and there were no more mothers with medium anxiety.

There is no statistically significant relationship between the level of knowledge and the degree of anxiety before (Table 4) and after (Table 5) treatment. The result from the knowledge of series one card was; mothers with an adequate knowledge level who experienced mild anxiety were 15 people and who experienced medium anxiety were two people. On the knowledge of series 2-3 cards, mothers with an adequate knowledge level who experienced mild anxiety were 20 people, and who experienced medium anxiety are five. Whereas, in the posttest treatment group, the level of good knowledge was proven to reduce the degree of anxiety of mothers who initially had medium or mild anxiety to be not anxious, but there were still 10 mothers who experienced mild anxiety.

\section{Discussion}

The process of learning or thinking that occurs in the memory system of the human brain produces a model of information processing in the learning process (theory learning). When an individual receives certain information or stimulus, it will be detected by sensory systems in the brain. It

Table 3 Differences of ZSAS's Anxiety Degree on Interventions before and after the Provision of Reproductive Health Education with Flashcard Media

\begin{tabular}{lccc}
\hline \multirow{2}{*}{ ZSAS's Anxiety Degree } & \multicolumn{2}{c}{ Groups (n=30) } & \multirow{2}{*}{ p Value $^{*}$} \\
\cline { 2 - 3 } & Pretest & Posttest & \\
\hline No anxiety & 0 & 20 & 0.000 \\
Mild anxiety & 24 & 4 & \\
Medium anxiety & 6 & 6 & \\
\hline Note: "Chi-square/Fisher & \multicolumn{4}{c}{}
\end{tabular}

Note: ${ }^{*}$ Chi-square/Fisher exact test 
Table 4 Relationship between Level of Knowledge and ZSAS's Anxiety in Both Groups before the Provision of Reproductive Health Education with Flashcard Media

\begin{tabular}{|c|c|c|c|c|}
\hline \multirow{2}{*}{ Knowledge Level } & \multicolumn{2}{|c|}{ ZSAS Anxiety Pretest Group $(n=30)$} & \multirow{2}{*}{ Total } & \multirow{2}{*}{ p Value } \\
\hline & Mild Anxiety & Medium Anxiety & & \\
\hline \multicolumn{5}{|l|}{ Card series 1} \\
\hline Inadequate & 9 & 4 & 13 & 0.240 \\
\hline Adequate & 15 & 2 & 17 & \\
\hline Total & 24 & 6 & 30 & \\
\hline \multicolumn{5}{|l|}{ Card series $2-3$} \\
\hline Inadequate & 4 & 1 & 5 & 0.360 \\
\hline Adequate & 20 & 5 & 25 & \\
\hline Total & 24 & 6 & 30 & \\
\hline
\end{tabular}

Note: *Chi-square/Fisher exact test

will create a learning process of an individual, and the results of processing stored in memory in the form of knowledge, that will be used later in a real event. ${ }^{10}$ This sensory system is composed of receptors and connecting neurons from the five senses (hear, see, smell, taste, and feel), and the area that processes visual information is the occipital lobe and actively connected to the prefrontal cortex as the center of rational thinking. ${ }^{10,22}$

The tool serves to facilitate the continuity of the learning process based on the principle that the knowledge possessed by every human being is received or captured through the senses, where someone can remember $50 \%$ of what was seen and heard. The result is consistent with Dale's learning experience, which stated that in learning, humans use $75 \%$ visual and $13 \%$ audio sensory, so the more senses are used to receive information, the more clear the knowledge obtained. ${ }^{14,15,19,23}$

Based on the study conducted by Pipitcahyani and Safitri, ${ }^{17}$ the results showed a significant difference between the flipchart groups and the flashcard group, an increase in knowledge in the intervention group reached $90 \%$ and in the control group was only $30 \%$ in mothers who had a good level of knowledge.

At present, we did not find any theories or other studies that conflicted with the effectiveness and the use of flashcard learning media. As Muhson said, ${ }^{24}$ learning media is a tool that can be manipulated and used to affect student's minds, feeling, attention, and attitude. Flashcards can help the learning process easier. A similar study that supports that opinion suggested that in balancing the functions of the left brain and the right brain with a flashcard media is quite sufficient to boost the ability of children, this even considered as one of the right stimuli in the child's brain to be given as early as possible. ${ }^{16}$

Anxiety is an emotional experience that arises because of an unclear threat or something that is not objective, both from outside and within the individual. ${ }^{25}$ Anxiety is closely related to the hypothalamic-pituitary-adrenal axis, which can cause stress hormone release, including

Table 5 The Relationship between the Level of Knowledge of the Card Series 1,2,3 on Anxiety in the Group after was Given Reproductive Health Education with Flashcard Media

\begin{tabular}{|c|c|c|c|c|}
\hline \multirow{2}{*}{ Knowledge Level } & \multicolumn{2}{|c|}{ ZSAS Anxiety Posttest Group $(n=30)$} & \multirow{2}{*}{ Total } & \multirow{2}{*}{ p Value ${ }^{*}$} \\
\hline & No Anxiety & Mild Anxiety & & \\
\hline \multicolumn{5}{|l|}{ Card series 1} \\
\hline Good & 20 & 10 & 30 & 0.720 \\
\hline Total & 20 & 10 & 30 & \\
\hline \multicolumn{5}{|l|}{ Card series $2-3$} \\
\hline Good & 20 & 10 & 30 & 1.000 \\
\hline Total & 20 & 10 & 30 & \\
\hline
\end{tabular}

Note: "Chi-square/Fisher exact test 
adrenocorticotropic hormone, cortisol, betaendorphin, growth hormone (GH), prolactin, and luteinizing hormone $(\mathrm{LH})$ or follicle stimulating hormone (FSH). If these stress hormones appear excessively, it will affect the increased risk of congenital abnormalities in the fetus. The risks are labio-palate, risk of birth with a caesarian, labor with a tool, premature birth, low birth weight (LBW), stunting, behavior, and emotional disorders of children in the long run..$^{26,27}$ Also, at risk for complications of labor and postpartum. ${ }^{28}$

Before the release of these hormones, anxiety was initially centered and sourced from the brain. A good level of knowledge in a person will reduce anxiety. In adolescent primigravidas, the information about reproductive health is still very minimal, and it will increase anxiety.

Knowledge form through the learning process. Knowledge of cognitive ability is a fundamental domain for the formation of one's actions. ${ }^{29}$ Through reproductive health education with flashcard media, it can divert attention and activate thinking functions in the brain (active prefrontal cortex function), which is the cognitive center of the individual. ${ }^{22,30}$

This theory supported by Bak and Mastalerz, ${ }^{31}$ which stated there was a relationship between age and the subjective assessment or education of women and fear of childbirth. Education differentiates the ability to apply in practice the knowledge and skill learned in Lamaze classes. The older the woman is, the more likely she is to experience anxiety as she approaches or during birth. Both older women and younger women need more mental support to increase their awareness and capabilities because anxiety during pregnancy can lead to premature birth and low birth weight, also another complication risk.

Another study that supports is Agarwal et al. ${ }^{11}$ stated that with an increase in the learning process, it could reduce anxiety by up to $72 \%$ in middle and high school students tested in the final semester. A similar study that was conducted by Ossai, also showed that the learning affects the degree of anxiety and achievement of students, one of them with flashcard training that students can learn in improving their ability to process information and think critically. ${ }^{32}$

In this study, the use of flashcard learning media in the delivery of reproductive health education is very influential on changes in the degree of anxiety. These changes related to increased knowledge experienced by mothers.
Although after statistical tests, there is no meaningful relationship between anxiety and maternal knowledge. The results might be caused by mothers who still experience mild anxiety, and there is no control group as a comparison.

However, in the further development of this study, it is necessary to have a control group with a different treatment. Role-playing simulation method, video, and card games involving many family members were some examples. If this media is applied directly in real life, the absorption of knowledge obtained will be better, and the use of the media will be more optimal.

\section{Conclusion}

The flashcard as a tool of learning is effective in increasing the level of knowledge and reduce the anxiety of adolescents primigravida mothers.

\section{Conflict of Interest}

TAll authors stated that there was no conflict of interest in this article.

\section{Acknowledgments}

Thanks to the Center for Quality Improvement Human Resources of Health, the Board for Development and Empowerment Human Resources of Health, Ministry of Health of the Republic of Indonesia, who have helped scholars for the implementation of this study. Thanks to the Faculty of Visual Communication Design, Institut Teknologi Bandung, who assisted in the design of this flashcard media.

\section{References}

1. United Nations International Children's Emergency Fund (UNICEF) Indonesia. Child marriage in Indonesia: progress on pause [Internet]. 2016 November [cited 2019 January 20]. Available from: https:// www.girlsnotbrides.org/wp-content/ uploads/2016/11/UNICEF-Indonesia-ChildMarriage-Research-Brief-1.pdf.

2. Statistics Indonesia (BPS), National Population and Family Planning Board (BKKBN), Ministry of Health (Kemenkes), ICF. Indonesia demographic and health survey 2012. Jakarta: BPS, BKKBN, Kemenkes, ICF; 2013.

3. Gipson JD, Koenig MA, Hindin MJ. The 
effects of unintended pregnancy on infant, child, and parental health: a review of the literature. Stud Fam Plann. 2008;39(1):1838.

4. Hanum Y, Tukiman. Dampak pernikahan dini terhadap kesehatan alat reproduksi wanita. JKSS. 2015;13(2):36-43.

5. Lee-Rife S, Malhotra A, Warner A, Glinski AM. What works to prevent child marriage: a review of the evidence. Stud Fam Plann. 2012;43(4):287-303.

6. Omidvar S, Faramarzi M, Hajian-Tilak K, Nasiri Amiri F. Associations of psychosocial factors with pregnancy healthy life styles. PLoS One. 2018;13(1):eo191723.

7. Bustos M, Venkataramanan R, Caritis S. Nausea and vomiting of pregnancy - what's new? Auton Neurosci. 2017;202:62-72.

8. World Health Organization (WHO). Mental health aspects of women's reproductive health: a global review of the literature. Geneva: WHO Press; 2009.

9. Susanti NN. Psikologi kehamilan. Jakarta: EGC; 2008.

10. Solso RL, Maclin OH, Maclin MK. Psikologi kognitif. $8^{\text {th }}$ Edition. Jakarta: Penerbit Erlangga; 2008.

11. Agarwal PK, D’Antonio L, Roediger HL III, McDermott KB, McDaniel MA. Classroombased programs of retrieval practice reduce middle school and high school students' test anxiety. J Appl Res Mem Cogn. 2014;3(3):131-9.

12. Larasati IP, Wibowo A. Pengaruh keikutsertaan senam hamil terhadap kecemasan primigravida trimester ketiga dalam menghadapi persalinan. JBK. 2012;1(1):26-32.

13. Dunkel Schetter C, Tanner L. Anxiety, depression and stress in pregnancy: implications for mothers, children, research, and practice. Curr Opin Psychiatry. 2012;25(2):141-8.

14. Daryanti, Firman, Neviyarni. Peran media pembelajaran dalam meningkatkan kemampuan siswa menulis. J Basicedu. 2019;3(4):2089-94.

15. Permatasari I. Pengaruh media pembelajaran audio-visual dan media cetak terhadap minat belajar siswa kelas VIII pada mata pelajaran fiqih di MTS Ma'arif Udanawu Blitar [undergraduate thesis]. Tulungagung: Institut Agama Islam Negeri Tulungagung; 2017 [cited 2019 February 28]. Available from: http://repo.iain-tulungagung.ac.id/6891. 16. Hayati N. Menstimulus otak kiri dan otak kanan anak dengan flash card [Internet]. Yogyakarta: Universitas Negeri Yogyakarta; 2007 [cited 2019 March 8]. Available from: http://staff.uny.ac.id/sites/default/files/ Artikel\%20Flash\%20Card.pdf.

17. Pipitcahyani TI, Safitri CA. The effectiveness of "flash card" in improving mothers' knowledge on pregnancy. Proc Int Conf Appl Sci Health. 2017;2:151-7.

18. Lutfitasari H, Meikawati W, Salawati T. Efektivitas penyuluhan gizi dengan media flash card dan poster dalam peningkatan pengetahuan siswa tentang keamanan makanan jajanan sekolah (studi pada siswa SDN Pandean Lamper o3 Semarang) [undergraduate thesis]. Semarang: Universitas Muhammadiyah Semarang; 2017 [cited 2019 April 10]. Available from: http:// repository.unimus.ac.id/1041.

19. Mahnun N. Media pembelajaran (kajian terhadap langkah-langkah pemilihan media dan implementasinya dalam pembelajaran). An-Nida'. 2012;37(1):27-34.

20. Swarjana IK. Statistik kesehatan. Yogyakarta: Penerbit ANDI; 2016.

21. Dahlan MS. Statistik untuk kedokteran dan kesehatan: deskriptif, bivariat, dan multivariat. $6^{\text {th }}$ Edition. $3^{\text {rd }}$ Printing. Jakarta: Epidemiologi Indonesia; 2015.

22. Kuswana WS. Taksonomi berpikir. Bandung: Rosda; 2011.

23. Masters K. Edgar Dale's Pyramid of Learning in medical education: a literature review. Med Teach. 2013;35(11):e1584-93.

24. Muhson A. Pengembangan media pembelajaran berbasis teknologi informasi. JPAI. 2010;8(2):1-10.

25. Badrya L. Perbedaan tingkat kecemasan antara mahasiswa kedokteran laki-laki dan perempuan angkatan 2011 FKIK UIN Syarif Hidayatullah Jakarta dalam menghadapi ujian OSCE [undergraduate thesis]. Jakarta: Universitas Islam Negeri Syarif Hidayatullah; 2014 [cited 2019 May 3]. Available from: http://repository.uinjkt.ac.id/dspace/ handle/123456789/25818.

26. Leigh B, Milgrom J. Risk factors for antenatal depression, postnatal depression and parenting stress. BMC Psychiatry. 2008;8:24.

27. Glover V. Stress in pregnancy can change fetal and child development. In: Leach P, editor. Transforming infant wellbeing: research, 
policy and practice for the first 1001 critical days. Abingdon: Routledge; 2017. p. 98-106.

28. Zhao Y, Munro-Kramer ML, Shi S, Wang J, Zhao Q. Effects of antenatal depression screening and intervention among Chinese high-risk pregnant women with medically defined complications: a randomized controlled trial. Early Interv Psychiatry. 2019;13(5):1090-8.

29. Bascandziev I, Tardiff N, Zaitchik D, Carey S. The role of domain-general cognitive resources in children's construction of a vitalist theory of biology. Cogn Psychol. 2018;104:1-28.
30. Sadock BJ, Sadock VA, Ruiz P. Kaplan and Sadock's synopsis of psychiatry: behavioral sciences/clinical psychiatry. $11^{\text {th }}$ Edition. Philadelphia: Wolters Kluwer; 2015.

31. Bąk B, Mastalerz M. Effectiveness of childbirth classes in reducing anxiety before birth depending on age and education. Med Stud. 2016;32(1):10-7.

32. Ossai OV. Influence of study skills on test anxiety and levels and achievement of senior secondary school students in english language [thesis]. Nsukka, Nigeria: University of Nigeria Nsukka; 2012. 